\title{
Analysis of intraspecific polymorphism of Nitraria sibirica Pall. using the ISSR technique
}

\author{
Sofia A. Khozyaykina*, Evgeny V. Banaev \\ Central Siberian Botanical Garden SB RAS,630090 Novosibirsk, Russia
}

\begin{abstract}
The analysis of DNA polymorphism of Nitraria sibirica Pall. was carried out at 13 natural populations of the Republic of Altai and Altai Territory using the ISSR technique. Seven effective ISSR primers have been identified to analyze DNA polymorphism in $N$. sibirica. 99 DNA fragments were yielded at DNA amplification with these primers, 66 of them were polymorphic. The genetic distance Nei (D) between the studied populations of $N$. sibirica averaged 0.32 , at mean 0.09 - within populations. An identification ISSR marker has been revealed, which can be used to study the genetic variability of the genus Nitraria $L$. (Nitrariaceae) species.
\end{abstract}

\section{Introduction}

The genus Nitraria L. (Nitrariaceae) is a representative of the ancient desert flora and includes about 10 species [1,2]. The genus is widespread in the steppe, semi-desert and desert regions of Minor, Central, North and Central Asia, Southeast Europe, North Africa, Australia. This plant populations are confined to intrazonal soils highly salted [3].

Nitraria sibirica Pall. is the most widespread and polymorphic species growing in Central Asia, Kazakhstan, China, Mongolia, Siberia. Despite its significant range, these species populations are usually small numbered and vulnerable state in Siberia. To preserve local populations, $N$. sibirica is included in the regional Red Data Books of the Republic of Altai, Republic of Khakassia, Irkutsk Region, Transbaikal Territory, where this species has the 2nd or 3rd nature conservation status [4,5,6,7].

Studying the species genetic polymorphism is important to establish regularities of evolutionary transformations under certain environmental conditions, and elaborate techniques for specific genotypes conservation [8]. To research polymorphism in populations, DNA marker systems are the most convenient, characterized by significant polymorphism and non-dependent on environment conditions where the plant grows. The most practical and easily reproducible tools include techniques for amplifying genomic DNA with a high intraspecific variability [9]. The method of the intermicrosatellite sequences (ISSR) analysis is used to study the genetic relationship of objects, analysis of taxa genetic diversity and phylogeny, and is most effective to investigate variability within a single species [10]. When assessing the genetic diversity in natural populations of the genus Peganum, close to Nitraria, it was noted that ISSR markers reveal higher-level

\footnotetext{
* Corresponding author: skhozyaykina@gmail.com
} 
polymorphism compared to ITS and RFLP systems [12]. At the same time, applying ISSR marker system does not always allow tracing the correlation between the genetic divergence of samples and their geographic origin [13]. Choosing a molecular marker, adequate to a given task and a taxonomic level of objects, similar to the choice of a trait or a trait group in comparative morphological analysis, has a great influence on the topology of phylogenetic trees [14].

The study objective is to select ISSR primers to analyze Nitraria sibirica genetic variability.

\section{Materials and Methods}

DNA samples for genetic analysis were obtained of 22 samples of Nitraria ( N. sibirica, $N$. schoberi L.) collected during field studies in 2011-2020 at 13 natural populations of the Republic of Altai and Altai Territory (Table 1).

Table 1. Location of Nitraria populations

\begin{tabular}{|c|c|c|c|c|}
\hline № & Symbol & Species & $\begin{array}{c}\text { Title of } \\
\text { populations }\end{array}$ & Collecting place \\
\hline 1 & A1 & \multirow[t]{21}{*}{$N$. sibirica } & \multirow[t]{4}{*}{ Dzhira } & \multirow{4}{*}{$\begin{array}{l}\text { Altai Territory, Kulundina District, } \\
\text { Dzhira Lake eastern shore }\end{array}$} \\
\hline 2 & A2 & & & \\
\hline 3 & A3 & & & \\
\hline 4 & A4 & & & \\
\hline 5 & B1 & & \multirow[t]{2}{*}{ Kuchuk } & Altai Territory, Blagoveshchensk \\
\hline 6 & B2 & & & $\begin{array}{c}\text { District, Nizhny Kuchuk village } \\
\text { environs }\end{array}$ \\
\hline 7 & $\mathrm{C}$ & & Uglovskoe & $\begin{array}{l}\text { Altai Krai, Uglovsky District, } \\
\text { Uglovskoe village environs }\end{array}$ \\
\hline 8 & $\mathrm{D}$ & & Balansor & $\begin{array}{c}\text { Altai Territory, Uglovsky District, } \\
\text { Kruglyansky village, the Balansor } \\
\text { Lake shore }\end{array}$ \\
\hline 9 & $\mathrm{E}$ & & Tassor & $\begin{array}{l}\text { Altai Territory, Uglovsky District, } \\
\text { the Tassor Lake shore }\end{array}$ \\
\hline 10 & $\mathrm{~F}$ & & Chinkussor & $\begin{array}{l}\text { Altai Territory, Uglovsky District, } \\
\text { the Chinkussor Lake shore }\end{array}$ \\
\hline 11 & G & & Veseloyarsk & $\begin{array}{l}\text { Altai Territory, Rubtsovsk District, } \\
\text { Veseloyarsk village environs }\end{array}$ \\
\hline 12 & $\mathrm{H}$ & & Novenkoe & $\begin{array}{l}\text { Altai Territory, Loktevsky District, } \\
\text { Novenkoe village environs }\end{array}$ \\
\hline 13 & I & & Gornyak & $\begin{array}{l}\text { Altai Territory, Loktevsky District, } \\
\text { Gornyak village environs }\end{array}$ \\
\hline 14 & J1 & & \multirow[t]{3}{*}{ Rubtsovsk } & \multirow{3}{*}{$\begin{array}{c}\text { Altai Territory, Rubtsovsk city } \\
\text { environs }\end{array}$} \\
\hline 15 & $\mathrm{~J} 2$ & & & \\
\hline 16 & $\mathrm{~J} 3$ & & & \\
\hline 17 & K & & Pospelikha & $\begin{array}{c}\text { Altai Territory, Pospelikhinsky } \\
\text { District, Pospelikha village environs, } \\
\text { turn to Babylonsky village }\end{array}$ \\
\hline 18 & $\mathrm{~L}$ & & Tobeler & $\begin{array}{l}\text { Altai Republic, Kosh-Agach District, } \\
\text { Tobeler village environs }\end{array}$ \\
\hline 19 & N1 & & \multirow{3}{*}{$\begin{array}{l}\text { Kosh- } \\
\text { Agach }\end{array}$} & \multirow{3}{*}{$\begin{array}{l}\text { Altai Republic, Kosh-Agach District, } \\
13 \mathrm{~km} \text { of Kosh-Agach village, a lake } \\
\text { shore in the Chuya river valley }\end{array}$} \\
\hline 20 & $\mathrm{~N} 2$ & & & \\
\hline 21 & N3 & & & \\
\hline 22 & $\mathrm{X}$ & N. schoberi & Kuchuk & $\begin{array}{c}\text { Altai Territory, Blagoveshchensk } \\
\text { District, New Kuchuk village environs }\end{array}$ \\
\hline
\end{tabular}


DNA was isolated of $5 \mathrm{mg}$ leaf tissue dried by Liston et al (1990) methodology with CTAB protocol (Doyle and Doyle, 1987). PCR was carried out in a BIS-N M111-02 amplifier (BIS, Russia). The reaction mixture contained 10×Taq-buffer for PCR (BIORON), $10 \mathrm{mM} \mathrm{MgCl}$ (BIORON), $10 \mathrm{mM}$ ISSR primers, mixed (5 mM each) dNTPs (Medigen), $2 \mu \mathrm{l}$ of template DNA, 5U / $\mu$ l DFS-Taq DNA Polimerase (BIORON), water. The mixture volume for a sample was $25 \mu \mathrm{L}$. Samples were stained with SYBR Green.

Amplification took place according to the following protocol: Primary denaturation at $95^{\circ} \mathrm{C}-2 \mathrm{~min} ; 40$ cycles including DNA denaturation at $94^{\circ} \mathrm{C}-0.40 \mathrm{~min}$, primer annealing $-1 \mathrm{~min}$, chain elongation at $72^{\circ} \mathrm{C}-2 \mathrm{~min}$; final extension of chains at $72^{\circ} \mathrm{C}-5$ min. The amplified fragments were separated in an electrophoresis chamber in $1.5 \%$ agarose gel, the chamber was filled with $1 \times \mathrm{TBE}$ buffer. Electrophoresis results were visualized using a UV gel documentation system (Bio-Rad GelDoc XR+). Sixteen primers were tested for amplification efficiency of PCR products at 22 selected Nitraria samples. The level of polymorphism for each primer in percent was calculated by the formula $\mathrm{P}=$ $\mathrm{Np} / \mathrm{N} * 100$, where $\mathrm{Np}$ is the number of polymorphic fragments, $\mathrm{N}$ is the total number of fragments [15].

The dendrogram was created using software TREECON (version $1.3 \mathrm{~b}$ ) by the UPGMA method with bootstrap support - 100 pseudoreplicas [16]. Genetic distances were calculated according to Ney [17].

\section{Results}

Seven ISSR primers were identified, which reproduced the clearest profiles on electrophoregrams (Table 2).

Table 2. Characteristics of ISSR primers used to study the variability of $N$. sibirica.

\begin{tabular}{|c|c|c|c|c|c|}
\hline $\begin{array}{c}\text { Name of a } \\
\text { primer }\end{array}$ & $\begin{array}{c}\text { Nucleotide } \\
\text { sequence } \\
5-3\end{array}$ & $\begin{array}{c}\mathrm{T}_{\text {annealing, }} \\
\left({ }^{\circ} \mathrm{C}\right)\end{array}$ & $\begin{array}{c}\text { Number of } \\
\text { amplified } \\
\text { fragments }\end{array}$ & $\begin{array}{c}\text { Number of } \\
\text { polymorphic } \\
\text { fragments }\end{array}$ & $\mathrm{P}, \%$ \\
\hline $\mathrm{UBC} 807$ & $(\mathrm{AG})_{8} \mathrm{~T}$ & 52 & 10 & 8 & 80 \\
\hline $\mathrm{M} 11$ & $(\mathrm{CA})_{6} \mathrm{R}$ & 49 & 13 & 7 & 53,8 \\
\hline $17899 \mathrm{~A}$ & $(\mathrm{CA})_{6} \mathrm{~A}-<\mathrm{G}>$ & 47 & 12 & 10 & 83,3 \\
\hline $17898 \mathrm{~B}$ & $(\mathrm{CA})_{6} \mathrm{GT}$ & 42 & 9 & 5 & 55,5 \\
\hline $\mathrm{HB} 10$ & $(\mathrm{CAC})_{3} \mathrm{GC}$ & 51 & 20 & 14 & 86,6 \\
\hline $\mathrm{HB} 12$ & $(\mathrm{GA})_{6} \mathrm{CC}$ & 42 & 18 & 8 & 55,5 \\
\hline $17898 \mathrm{~A}$ & $(\mathrm{CA})_{6} \mathrm{AC}$ & 45 & 17 & 14 & 82,4 \\
\hline
\end{tabular}

\section{Discussion}

All profiles revealed 99 fragments, 66 of them were polymorphic. A ISSR primer initiated the synthesis of averaged 14.4 DNA fragments in $N$. sibirica. The number of amplified DNA fragments varied depending on the primer from 9 to 20, their sizes are 400-1530 bp. The primer HB 10 detected the largest number of loci, the primer $17898 \mathrm{~B}$ - the smallest one. The number of polymorphic loci detected by primers varied from 5 (primer $17898 \mathrm{~B}$ ) to 14 (the primer HB 10 and $17898 \mathrm{~A}$ ). 
Interspecies and interpopulation differences were revealed only by the primer UBC 807 (Fig. 1). Unique to N. schoberi fragments range from 600 to $700 \mathrm{bp}$, as well as in the spectrum region from $1000 \mathrm{bp}$. At the same time, N. schoberi lacks fragments in $900 \mathrm{bp}$ region, which are inherent in $N$. sibirica samples.

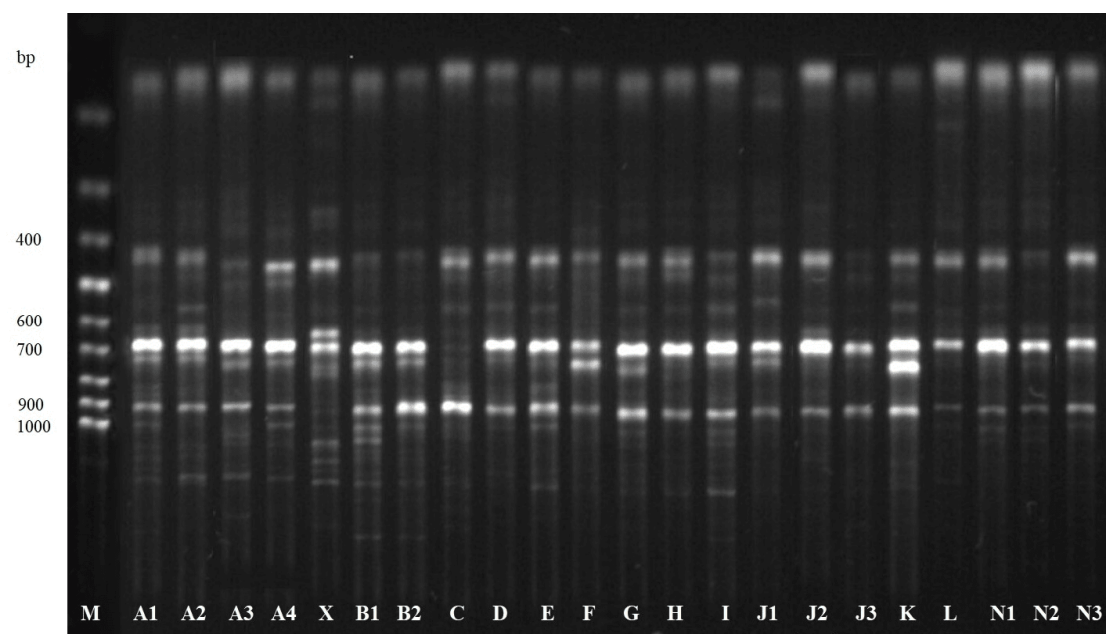

Fig. 1. ISSR profiles of fragments amplified with UBC 807 primer.

The genetic distance according to Ney (D) between $N$. sibirica and $N$. schoberi averaged $\mathrm{D}=0.63$, between populations of $N$. sibirica $-\mathrm{D}=0.32$, within populations of $N$. sibirica $\mathrm{D}=0.09$. In general, the intergroup differences are consistent with the geographic differentiation of $N$. sibirica populations (Fig. 2). The largest distances have been revealed between the populations of the high-mountainous Chuya steppe and the Kulunda flatland.

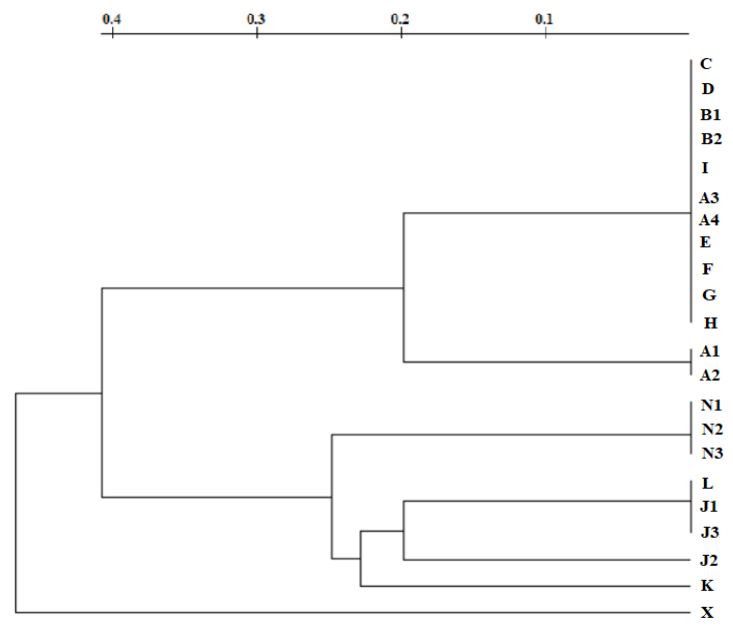

Fig. 2. Dendrogram of similarity of Nitraria samples, constructed by the UPGMA method based on the polymorphism of the ISSR marker UBC-807.

This study suggests the possibility of using the ISSR primer UBC 807 to analyze the phylogeography of $N$. sibirica. The revealed interpopulation differences in $N$. sibirica 
samples of geographically distant natural populations evidence their genetic differentiation during isolation in intrazonal communities.

Acknowledgments. When preparing a publication, the authors used materials of the bioresource scientific collection of the Central Siberian Botanical Garden of the Siberian Branch of SB RAS, USU "Herbarium of Higher Plants, Lichens and Fungi (NS, NSK)", USU_440537.

\section{References}

1. E. G. Bobrov O, Botanical journal, 50(8) (1965)

2. E. V. Banaev, M. A. Tomoshevich, M. B. Yamtyrov, Contemp. Probl. Ecol., 10(6) (2017)

3. S. A. Khudyaev, E. V. Banaev, Contemp. Probl. Ecol., 5 (2012)

4. Red List of Zabaykalsky Krai: Plants (Novosibirsk, 2017)

5. Red List of Altai Republic: Plants (Gorno-Altaysk, 2017)

6. Red List of Khakassia Republic: rare and endangered Species of Plants and Fungus (Novosibirsk, Nauka, 2012)

7. Red List of Irkutsk Region. (Irkutsk, 2010)

8. S. G. Inge-Vechtomov, VOGiS Bulletin, 13(2) (2009)

9. O. V. Dorogina, E. V. Zhmud, Contemp. Probl. Ecol., 13(4) (2020)

10. B. Bornet, M. Branchard, Plant Mol. Biol. Rep., 19 (2001)

11. J. J. Doyle, J. L. Doyle, Phytochem. Bull., 19 (1987)

12. R. EL-Bakatoushi, D. G. A. Ahmed, J. Genet. Eng. Biotechnol., 10(1) (2018)

13. Z. A. A. El-Kheir, M. O. El-Monayeri, D. A. EL-Raof, Al-Azhar, Bull. Sci., 17(2) (2006)

14. N. I. Abramson, VOGiS Bulletin, 11(2) (2007)

15. S. V. Asbaganov, E. V. Kobozeva, A. V. Agafonov, Vavilov J. Genet. Breed., 18(3) (2014)

16. Y. Peer Van de, R. D. Wachter, Comput. Appl. Biosci., 10 (1994)

17. M. Nei, W.-H. Li, Proc Natl Acad Sci., 76 (1979) 